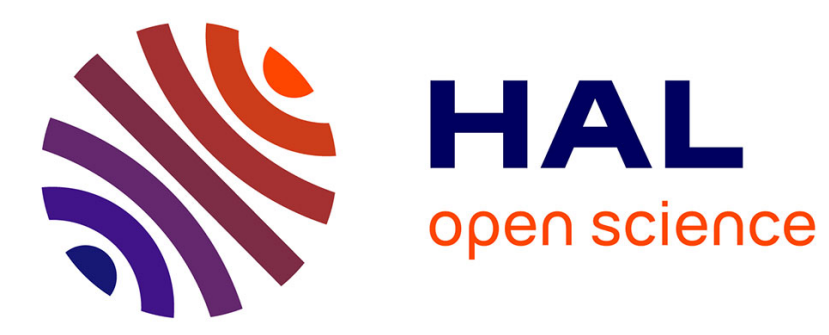

\title{
Pigments and photoacclimation processes
}

Christophe Brunet, Geir Johnsen, Johann Lavaud, Suzanne Roy

\section{To cite this version:}

Christophe Brunet, Geir Johnsen, Johann Lavaud, Suzanne Roy. Pigments and photoacclimation processes. Phytoplankton Pigments: Characterization, Chemotaxonomy and Applications in Oceanography, , 2011. hal-01101814

\section{HAL Id: hal-01101814 https://hal.science/hal-01101814}

Submitted on 9 Jan 2015

HAL is a multi-disciplinary open access archive for the deposit and dissemination of scientific research documents, whether they are published or not. The documents may come from teaching and research institutions in France or abroad, or from public or private research centers.
L'archive ouverte pluridisciplinaire HAL, est destinée au dépôt et à la diffusion de documents scientifiques de niveau recherche, publiés ou non, émanant des établissements d'enseignement et de recherche français ou étrangers, des laboratoires publics ou privés. 


\title{
Chapter 4.4: Pigments and photoacclimation processes
}

\author{
Christophe Brunet ${ }^{1}$, Geir Johnsen ${ }^{2}$, Johann Lavaud ${ }^{3}$, and Suzanne Roy ${ }^{4}$ \\ 1: Stazione Zoologica A. Dohrn, Villa Comunale, 80121 Napoli - Italy. \\ christophe.brunet@szn.it, \\ 2: Dept. of biology, Norwegian University of Science and Technology, Trondhjem \\ Biological Station, N-7491 Trondheim, Norway. \\ geir.johnsen@bio.ntnu.no, \\ 3. UMR CNRS 6250 'LIENSs' - Institute for Coastal Research and Environment (ILE) \\ University of La Rochelle - 2, rue Olympe de Gouges - 17000 La Rochelle Cedex - \\ France. \\ johann.lavaud@univ-lr.fr, \\ 4: Institut des Sciences de la Mer, Université du Québec a Rimouski, Rimouski, Quebec, \\ G5L 3A1, Canada. \\ suzanne_roy@uqar.qc.ca
}

\section{Content of the chapter}

\subsubsection{Long-term photoacclimative processes}

4.4.1.1. Chloroplast size, number, morphology and distribution

4.4.1.2. Light harvesting complexes and thylakoid membranes

4.4.1.3. Pigment composition and function

\subsubsection{The xanthophyll cycle and short-term photoacclimation}

4.4.2.1. Role and regulation of the xanthophyll cycle

4.4.2.2. The xanthophyll cycle and non-photochemical quenching

\subsubsection{The xanthophyll cycle and the ecological properties of phytoplankton}

4.4.3.1. Ecophysiology and environmental modulation of the xanthophyll cycle

4.4.3.2. The xanthophyll cycle and UV radiation

4.4.3.3. The xanthophyll cycle and the dynamics of water masses

\section{References}

Acknowledgements 
This chapter reviews the nature of pigment variations in phytoplankton in response to changes in light regime (irradiance, spectral composition and daylength). These changes belonging to processes called acclimation and/or adaptation maximize the evolutionary fitness of a species, within the constraints set by the environmental conditions (Raven and Geider, 2003). In general, adaptation indicates long-term evolutionary outcome based on the genes a given species obtains (genetic adaptation) while acclimation denotes adjustments in response to variation in key-environmental variables (physiological acclimation).

Photo-acclimation corresponds to a mosaic of processes involving many cellular components and occurring over a broad range of time scales, from seconds to days. These processes, covering many physiological, biochemical, biophysical and biological changes, allow the optimization of cell activities, such as photosynthesis, respiration, growth and division when faced with changing irradiance (e.g., Herzig and Dubinsky, 1993; Anning et al., 2000; Raven and Geider, 2003). This is an important issue in phytoplankton ecology because of the fluctuating light environment experienced by pelagic algae, related to daylight variations together with the exponential decrease of light and the vertical - active or passive - movements of algae along the water column.

In order to cope with these never-ending fluctuations in light-regime, marine phytoplankton can adjust their pigment pool, which is mainly constituted by two functional categories, namely pigments used for light harvesting and for photoprotection. Many accessory pigments constituting the light-harvesting complexes are photosynthetically active i.e. they are able to transfer the energy absorbed from sunlight to the photosynthetic reaction centers (RC) of photosystems (PS) II and I. They are called light harvesting pigments and include the photosynthetic carotenoids. However, some carotenoids are not involved in photosynthesis and do not transfer the absorbed energy to the RC. These non-photosynthetically active carotenoids are also called photoprotective carotenoids (PPC).

The function and dynamics of long-term (hours-days) and short-term (minutes-hours) photo-acclimation are described in the following two sections (4.4.1 and 4.4.2, respectively). The long-term photo-acclimation response mainly consists in changes of structure and composition of the photosystems while the short-term photo-acclimation 
process mainly concerns the xanthophyll cycle (XC) activation and the associated nonphotochemical fluorescence quenching (NPQ). In the third section (4.4.3), the ecophysiological variability of XC and its use as a biological tracer in oceanographic studies is reported.

\subsubsection{Long-term photoacclimation}

In general, photoacclimation in a living cell is characterized by changes in the amount and ratios of light harvesting pigments and photoprotective carotenoids, in photosynthetic parameters, in enzymatic activities involved in photosynthesis and respiration, and finally, in cell volume and chemical composition (Falkowski and LaRoche, 1991). In this part, we will focus on changes in chloroplasts, light harvesting complexes, pigment composition and function.

\subsubsection{Chloroplast size, number, morphology and distribution}

The different phytoplankton classes and pigment-groups show huge differences in chloroplast size, numbers, morphology and distribution (Kirk and Tilney-Bassett, 1978; Larkum and Vesk, 2003). The chloroplast number is species-specific and varies from 1 chloroplast per cell to more than 100. An example can be given from the diatom genus Chaetoceros, were some species only contain one, other 2, 6 or more than 10 chloroplasts per cell. The species-specific differences in chloroplast size (typically $0.2-2 \mu \mathrm{m}$ in length) and morphology (shape and structure) in a given species is also affected as a function of light climate (irradiance, the spectral composition of irradiance and day length). Light-induced chloroplast changes in a given species will especially affect light harvesting and utilization (Raven and Geider, 2003), seen as changes in intracellular selfshading (the package effect, see chapter 4.3) and the optical signature from the chloroplast (colour, optical density, and in vivo fluorescence emission, Falkowski and Chen, 2003; Sakshaug and Johnsen, 2005; Johnsen and Sakshaug, 2007). Typically, low light (LL)-acclimated cells have chloroplasts evenly distributed in the cells (large light 
harvesting surface), while high light (HL)-acclimated cells have condensed chloroplasts (small light absorbing surface, Blatt et al., 1981).

\subsubsection{Light harvesting complexes and thylakoid membranes}

The majority of pigments in phytoplankton cells are situated inside the thylakoid membranes as discrete light harvesting complex, made up from pigment-protein complexes. The build-up of the different light harvesting complexes in the different phytoplankton classes is discussed in chapter 4.3. The light harvesting complexes in different phytoplankton classes differ in thylakoid membrane organization and in energy regulation mechanisms (Green et al., 2003). Most green algal thylakoids have both stacked and unstacked membrane regions, but often with the same PSI:PSII ratio in both regions (Bertos and Gibbs, 1998). In contrast, the chromophytes comprising Bacillariophyceae, Cryptophyceae, Dinopyceae, Pelagophyceae, Eustigmatophyceae, Chrysophyceae, Bolidophyceae, Pinguiophyceae, Raphidophyceae, Dictyochophyceae, haptophyta (comprising the two classes Coccolithophyceae and Pavlovophyceae) do not have lateral segregation of of PSII and PSI (Green et al., 2003). Lateral segregation of PSII and PSI in Rhodophyta and in most Chlorophyta is related to the ability of performing state transitions (see chapter 4.3).

The majority of chromophytes contain large light harvesting complexes associated with PSII where the fraction of light harvesting pigments and PPC is tuned as a response to light history. The fraction of pigment-specific absorption of light is highly dependent on the photo-acclimation status of algae and water colour (Johnsen et al., 1994; Schofield et al., 1996; Stolte et al., 2000; Johnsen and Sakshaug, 2007, Fig. 1). Generally HL-acclimated cells are characterized by low light harvesting pigment content and a corresponding high amount of PPC, and a corresponding inverse relationship for LL-acclimated cells (Johnsen et al., 1997; Stolte et al., 2000; Falkowski and Chen, 2003; Rodriguez et al., 2006). Isolated and functional light harvesting complexes (that are able to transfer light energy to acceptor chlorophyll $a$ ) differ in LL and HL-acclimated cells of a given species (Johnsen et al., 1994, 1997). For example, HL-acclimated dinoflagellates may have a significant amount of diadinoxanthin in the antenna (denoted chla-chlc- 
peridinin protein $=\mathrm{ACP}$ ) that does not transfer light energy to chl $a$. This can be seen by using spectral absorption coefficients (indicating the total amount of light absorbed) and fluorescence excitation spectra (scaled at the red peak of chla assuming $100 \%$ light energy transfer efficiency) indicating the fraction of light that is received by acceptor chla. This analysis shows that ACP antennas from HL acclimated cells with high photoprotective caraotenoids (PPC, diadinoxanthin and diatoxanthin) relative to chla (49\%,w:w) have low relative light transfer efficiency at the absorption peaks of the PPCs at $490(15-20 \%)$ and $460 \mathrm{~nm}(20-30 \%$, Johnsen et al., 1997). In contrast, ACP antennas from LL-acclimated cells with $15 \%$ PPC relative to chla, reach $70-80 \%$ relative light energy transfer efficiency at 490 and $460 \mathrm{~nm}$. Johnsen et al. (1997) also showed that wavelengths from 550-700 nm, where PPCs do not absorb, have a close to $100 \%$ relative light energy transfer efficiency.

The energy regulation mechanisms in the light harvesting complexes, that are different between phycobiliprotein, chlc and chlb-containing phytoplankton, are state transitions (e.g. phosphorylation and de-phosphorylation causing movement of light harvesting complexes in the PS II) and xanthophyll cycle caused by $\Delta \mathrm{pH}$ (see section 4.4.2.). State transitions and the xanthophyll cycle affect the effective absorption cross section of PSII, $\sigma_{\text {PSII }}$, defined as the efficiency of absorbed quanta to drive a photochemical reaction in $\AA$ ngstrom $\left(\AA^{2}\right.$ quanta $\left.^{-1}\right)$ indicating a quantum yield of charge separation (Falkowski and Chen, 2003).

In contrast, the spectrally integrated chla-specific absorption coefficient (400-700 $\mathrm{nm}), \mathrm{a}_{\varphi}\left(=\right.$ optical cross section, units: $\left.\mathrm{m}^{2} \mathrm{mg} \operatorname{chl} a^{-1}\right)$ indicates the total pigment-protein absorption by the cell. Both $\mathrm{a}_{\varphi}^{-*}$ and $\sigma_{\mathrm{PSII}}$ are spectrally dependent, inducing pigmentspecific differences in photosynthetic efficiency as a function of wavelengths. Regarding PSII and photosynthesis, $\sigma_{\text {PSII }}$ can be determined for a single wavelength and extrapolated to other wavelengths from knowledge of the PSII-fluorescence excitation spectra (Johnsen et al., 1997; Falkowski and Chen, 2003; Johnsen and Sakshaug, 2007). Changes in cross-sectional area of PSII and PSI due to re-association of mobile light harvesting complexes of the PS II (i.e. state transitions) contribute to $<20 \%$ change in cross-section areas (Larkum, 2003). This indicates that it is the light harvesting complexes and their pigments that contribute to the major fraction of photo-acclimation in phytoplankton and 
that state-transitions (which occur on a minute scale) only contribute to a small fraction in absorption cross-section changes (Larkum, 2003; Raven and Geider, 2003).

\subsubsection{Pigment composition and function}

The high pigment diversity in light harvesting complexes, relative to the more conservative pigment composition in PSII and PSI, is responsible for the high pigmentgroup specific differences in light harvesting and utilization. In most bloom-forming phytoplankton, some light harvesting pigments are of high importance; these are the peridinin, prasinoxanthin, violaxanthin and the fucoxanthins (including acyl-oxy derivatives). From the ratios between photosynthetic pigments, distinct pigment-groups have been defined in the Prasinophyceae (e.g., Hooks et al., 1988; Egeland et al., 1995; Zingone et al., 2002) or in the haptophyta (e.g., Stolte et al., 2000; Zapata et al., 2004).

Generally, chl $a$ is not an important pigment in light harvesting. Its major role is to receive light energy from donor pigments in light harvesting complex and it is one of the key molecules in the photochemical conversion of light energy to chemically bonded energy in the RC. Usually pigment data are normalized to chla as biomass. Since cellular chl $a$ content in a given species is highly light-regime dependent, the less variable Particulate Organic Carbon (POC) is a better biomass indicator (Johnsen and Sakshaug, 1993; Brunet et al., 1996; Rodriguez et al., 2006). The interpretation of light harvesting pigments and PPC in HL and LL conditions is therefore highly dependent on biomass normalization (chla vs. POC, Rodriguez et al., 2006; Johnsen and Sakshaug, 2007). The chla:C ratio (w:w) is low in high light (and long day length) and high in low light. Thus, the chla:C (w:w) ratio indicates the photo-acclimation status and is termed photoacclimation index (Sakshaug et al., 1997). The photo-acclimation index can be described as a function of absorbed quanta (Nielsen and Sakshaug, 1993). Averaged chla:C ratios for HL- and LL-acclimated cells of 10 phytoplankton classes were 0.020 and 0.043 , respectively (Johnsen and Sakshaug, 2007). Since chla and light harvesting pigments covary (Johnsen et al., 1997; Rodriguez et al., 2006; Johnsen and Sakshaug, 2007), the variation in light harvesting pigments: $\mathrm{C}$ ratio will follow the corresponding variation in chla:C ratio. In general, there are some common long-term photo-acclimation 
characteristics. The faster the growth rate, the faster the acclimation process, since cells are dependent on rapid division to adjust to the key-environmental variables. Light history has also a relevant effect on the overall acclimative response of the cells (e.g., Anning et al., 2000) and can be a determinant factor for the kinetic of some processes and pigment variations (Anning et al., 2000; Dimier et al., 2007b).

\subsubsection{The xanthophyll cycle and short term photoacclimation}

\subsubsection{Role and regulation of the xanthophyll cycle}

When chlorophyll (chl) $a$ molecules of the light harvesting complexes antenna absorb light they enter a singlet-state excitation ${ }^{1} \operatorname{chl} a^{*}$ from which energy is deactivated following several pathways. Most of the excitation energy is used to drive photochemistry, through charge separation within the reaction center of photosystems, with some associated leaks: reemission of the energy via chlorophyll fluorescence and heat. There is nevertheless a non-negligible part of the energy which can be dissipated through the 'triplet valve' thereby forming triplet-state excitation: $\operatorname{chl} a+\operatorname{light} \rightarrow{ }^{1} \operatorname{chl} a^{*}$ $\rightarrow{ }^{3} \operatorname{chl} a^{*}$. This pathway depends on the lifetime of ${ }^{1} \operatorname{chl} a^{*}$ which itself depends on the other deactivation pathways. When the light absorbed is in excess (i.e. under a high light exposure) and the ability of the photosynthetic machinery to use the excitation energy via photochemistry is at its maximum, the yield for chla fluorescence increases and the

probability of ${ }^{3} \mathrm{chl} a^{*}$ formation increases. This situation is critical since ${ }^{3} \mathrm{chl} a^{*}$ can react with oxygen $\left(\mathrm{O}_{2}\right)$ within the PS II reaction center, generating reactive $\mathrm{O}_{2}$ species such as singlet ${ }^{1} \mathrm{O}_{2}$ * which are very harmful for proteins, pigments and lipids and lead to a decrease in the rate of photosynthesis. Photosynthetic organisms are able to maintain a low steady-state of ${ }^{3} \mathrm{chl} a^{*}$ generation through several rapid 'photoprotective' mechanisms which help to minimize the production of reactive oxygen species. Non-photochemical fluorescence quenching (NPQ) is believed to be the most important of these processes and the carotenoid xanthophylls play a central role in photoprotection, especially via the Xanthophyll Cycle (XC). 
The xanthophyll cycle involves the enzymatic de-epoxidation/epoxidation of acetylenic xanthophylls, synthesized from $\beta$-carotene (Lohr and Wilhelm, 2001), as a function of of absorbed quanta. There are two groups of organisms, which can be defined on the basis of the pigments involved in the $\mathrm{XC}$ (Table II). A first group includes as the main $\mathrm{XC}$ the two-step de-epoxidation of violaxanthin $(\mathrm{Vx})$ into zeaxanthin $(\mathrm{Zx})$ via antheraxanthin $(\mathrm{Ax})$. A second group includes the one step de-epoxidation of diadinoxanthin (Dd) into diatoxanthin (Dt), Dt showing the same degree of deepoxidation Zx. A third group includes the phyla in which there is no XC but an accumulation of Zx directly from $\beta$-carotene under high light exposure (a few species of red macroalgae show a XC (Raven and Geider, 2003). Within group 1, some prasinophytes have been shown to be unable to convert Vx further than Ax (Goss et al., 1998) and some green macroalgae have no XC (Raven and Geider, 2003). In addition, a second XC, which is not always minor, has been reported in several plant species and in the green microalga Chlamydomonas involving the de-epoxidation of lutein-epoxide into lutein under certain circumstances like prolonged high light stress (Rascher and Nedbal, 2006). Additionally, in the green macroalga Caulerpa, a secondary XC involving conversion between lutein and siphonaxanthin (biosynthetically related to siphonein) has been reported (Raniello et al., 2006). Within the second group, there are also some phyla showing a second XC. They include some Heterokontophyta (Bacillariophyceae, Chrysophyceae, Xanthophyceae), Haptophyta and Dinophyta, showing the Vx-cycle under prolonged high light stress (Lohr and Wilhelm, 2001). It is still unclear whether the temporary accumulation of Zx under high light conditions is only an unavoidable consequence of the properties of the $\mathrm{XC}$ or if it has a real physiological significance by increasing the photoprotective ability of the chloroplast. Interestingly, for an unknown reason, among the Heterokontophytes, some very close phyla evolved towards the $\mathrm{Vx}$ cycle as the main XC (the brown algae) while others (like the diatoms) evolved towards the Dd-cycle.

The regulation and operation of the XC (Fig. 2) has been described in details earlier, especially for the Vx-cycle (Latowski et al., 2004). The de-epoxidation/epoxidation events are ensured by two enzymes, a Vx de-epoxidase (VDE) and a Zx epoxidase (ZEP) which are part of the few (in contrast to animals) lipocalin proteins known in plants. VDE 
is localized on the lumen side and can bind/unbind to the thlyakoid membrane as a function of the lumenal $\mathrm{pH}$, its optimal $\mathrm{pH}$ activity being around 5-6. ZEP is localized on the stroma side; its $\mathrm{pH}$ optimum is 7.5. In addition, VDE needs the acid form of ascorbate as a co-factor and ZEP needs NADPH, $\mathrm{H}^{+}$and oxygen. The operation of the $\mathrm{XC}$ results in the competition of the activity of these two enzymes as a function of the built-up of the transthylakoid proton gradient, which is driven by the irradiance-dependent photosynthetic electron transport rate and subsequent change in lumenal and stromal $\mathrm{pH}$. In summary, when the irradiance is moderate to high, the lumenal $\mathrm{pH}$ drops down to values between 4.5 - 6.5. When the irradiance decreases to darkness, the de-epoxidation becomes weaker and finally stops, while the reverse epoxidation reaction, which is ten times slower, becomes dominant (note that ZEP is also active under high light). Hence, the accumulation of the photoprotective de-epoxidized xanthophylls Zx and Dt under an excess of light is dependent on the activity of the two enzymes which indirectly depends (via the change in $\mathrm{pH}$ and availability of the co-factors) on the irradiance. In the organisms displaying the Dd-cycle, a similar mechanism has been described with some special features. The Dd de-epoxidase (DDE) has been shown to be able to de-epoxidize Dd as well as Vx, which has been used as an explanation for the presence of the two XC in several phyla (Jakob et al., 2001). Nevertheless, two genes have recently been found in the genome of the diatom Phaeodactylum tricornutum that encode for two homologues of the VDE ('VDE-like' genes) in addition to the gene coding for DDE (A. Gruber, pers. com.). In contrast to VDE, DDE $\mathrm{pH}$ optimum is shifted towards higher $\mathrm{pH}$ and is active even at $\mathrm{pH}$ values about 7 (Jakob et al., 2001). Consequently, Dd de-epoxidation can already be triggered by a weak lumen acidification induced by, for example, chlororespiration (Jakob et al., 1999). It also means that the Dd de-epoxidation already occurs for lower light intensities and shorter illumination times than the Vx deepoxidation. Additionally, a recent study (Grouneva et al., 2006) showed that DDE requires much lower ascorbate concentration than VDE to be fully effective. Finally, DDE requires a lower concentration of lipids MGDG (monogalactosyldiacylglycerol) to drive efficient de-epoxidation meaning that higher Dd amounts can be converted under high light (Goss et al., 2005). Regarding the analogue of ZEP, the Dd epoxidase also shows an interesting characteristic: it is inactivated under excess light, which completely 
switches the equilibrium of the XC towards Dt accumulation (Goss et al., 2006). All together these special features of the Dd-cycle explain the surprising efficiency and rapidity of accumulation of Dt in large amounts (Lavaud et al., 2002a; Lavaud et al., 2004). Finally, in diatoms, a species-dependent de novo synthesis of Dt under prolonged high light stress allows the cells to increase their capacity for photoprotection (Lavaud et al., 2004).

\subsubsection{The xanthophyll cycle and non photochemical quenching}

The NPQ process takes place into the light harvesting complexes of the PS II and its role is to dissipate as heat or reallocate part of the excitation energy before it reaches the reaction center when the light has been absorbed in excess during a light exposure which exceeds the ability of the photosynthetic machinery to use all the energy for photochemistry. NPQ reduces the lifetime of ${ }^{1} \operatorname{chl} a^{*}$ and, as a consequence, the quantum yield of chla fluorescence as well as the quantum yield of photochemistry. NPQ can be divided into three components: $\mathrm{qE}$, the energy-dependent quenching which is regulated by the build up of a transthylakoid $\Delta \mathrm{pH}$ and the operation of the $\mathrm{XC}$; qT, the statetransition quenching which allows reallocation of part of the energy absorbed from the PS II to the PS I; qI, the photoinhibitory quenching. Here, we will focus on the $\mathrm{qE}$ component. qE has been investigated up to both molecular (down to few $\AA$ ) and gene levels, especially in higher plants and green microalgae (Cogdell, 2006; Jung and Niyogi, 2006), far less in other eukaryotic algae and cyanobacteria.

The first correlation between $\mathrm{qE}$ and the accumulation of de-epoxidized xanthophylls under high light was observed in higher plants and green microalgae (see DemmigAdams, 1990). Later it was also reported in diatoms and dinoflagellates (Sakshaug et al., 1987; Demers et al., 1991; Olaizola and Yamamoto, 1994), Chrysophyceae (or chrysophyta) and euglenophyta (Lichtlé et al., 1995; Casper-Lindley and Bjorkman, 1998), red algae (Ritz et al., 1999) and more recently in cyanobacteria (Bailey et al., 2005) and picoplanktonic chlorophyta (Dimier et al., 2007b). A linear relationship between the operation of the $\mathrm{XC}$, and the subsequent accumulation of zeaxanthin ( $\mathrm{Zx})$, antheraxanthin $(\mathrm{Ax})$ and diatoxanthin $(\mathrm{Dt})$, the development of $\mathrm{qE}$ and the quenching of 
chla fluorescence has been described in detail earlier (Gilmore and Yamamoto, 1991; Lavaud et al., 2002a). The model for the $\mathrm{qE}$ mechanism is well understood in higher plants and green microalgae (Holt et al., 2004; Horton et al., 2005; Cogdell, 2006). In summary, it implies a feed-back reaction from the linear electron transport via the builtup of a transthylakoid $\Delta \mathrm{pH}$ and subsequent acidification of the lumen of the thylakoid: the higher the irradiance, the higher the electron transport and coupled translocation of protons, the higher the accumulation of protons into the lumen. This acidification has two consequences: the protonation of specific sites of a special light harvesting complexes protein identified as PsbS in higher plants and the activation of VDE for synthesis of Zx. Both events enable the light harvesting complexes antenna to switch from a lightharvesting to a dissipative mode where excess excitation energy is converted into heat while chla fluorescence is quenched.

The other group in which the $\mathrm{qE}$ mechanism and its relationship with the $\mathrm{XC}$ has been investigated in details are the diatoms (Olaizola et al., 1994; Lavaud et al., 2002a). qE can be up to 4-5 times higher in diatoms than in plants (Lavaud et al., 2002a; Ruban et al., 2004), making it the most important rapid photoprotective process. It has been argued that this is due to the absence of state-transitions in diatoms (Owens, 1986). Other differences have been listed earlier in detail (Wilhelm et al., 2006). They include a different light harvesting complexes organization (Büchel, 2003; Guglielmi et al., 2005) and especially the absence of PsbS, a different localization of the xanthophylls within the light harvesting complexes (Lavaud et al., 2003; Beer et al., 2006), a capacity for accumulating large amounts of xanthophylls and a different composition and regulation of the XC. Additionally, qE appears to be more tightly associated with the XC and the accumulation of Dt than in plants with Zx (Lavaud et al., 2002a) so that both the transthylakoid $\Delta \mathrm{pH}$ and $\mathrm{XC}$ have a strong role in finely regulating $\mathrm{qE}$ (Lavaud et al., 2002b; Ruban et al., 2004; Goss et al., 2006). Part of the $\mathrm{qE}$ process in diatoms remains to be elucidated, however recent advances (Lavaud and Kroth 2006) contributed to the development of a first mechanistic model (Goss et al., 2006).

The red algae and cyanobacteria have extrinsic light harvesting complexes system (i.e. phycobilisomes) and also show a $\mathrm{qE}$ process even though the amplitude is weak. The same remark holds true for Prochlorococcus and its intrinsic Pcb antenna system (Bailey 
et al., 2005). qE in these organisms does not depend on a XC but on high light dependent $\mathrm{Zx}$ accumulation. Actually a XC has been observed in some species of red algae, but no link with $\mathrm{qE}$ has been reported (Ursi et al., 2003). In cyanobacteria, the process is believed to be a thermo-optic mechanism driven by blue light and taking place in the phycobilisomes where it involves a special carotenoid-binding protein and the pigments Zx and/or myxoxanthophyll (Cadoret et al., 2004; Wilson et al., 2006). It has been argued that $\mathrm{qE}$ in cyanobacteria would serve to adjust the energy transfer within the phycobilisomes of an already acclimated system to environmental stress(es) (high light, iron deficiency), but would not serve to cope with rapid fluctuations of irradiance as in higher plants and eukaryotic algae.

\subsubsection{The xanthophyll cycle and the ecological properties of phytoplankton}

\subsubsection{Ecophysiology and environmental modulation of the XC}

There are striking peculiarities of the algal XC activity with respect to terrestrial plants, including a high degree of variation in structure and activity of the $\mathrm{XC}$ among phytoplankton belonging to different taxa (Casper-Lindley and Bjorkman, 1998; Lavaud et al., 2004, Masojidek et al., 1999, 2004; Wilhelm et al., 2006). In addition, the XC activity depends on the physiological and nutritional state of the algae (Latasa and Berdalet, 1994; Staehr et al., 2002). This diversity may affect the survival and the growth of species under high light and therefore their competitive ability, affecting the patterns of algal succession in phytoplankton community (Demers et al., 1991; Lavaud et al., 2004). As an example of this, the $\mathrm{XC}$ and $\mathrm{qE}$ were shown to be involved in seasonal succession of diatoms in estuaries (Serodio et al., 2005), while a high qE appears to contribute to the domination of some diatom species in aquatic habitats where the light environment fluctuates strongly (Mitrovic et al., 2003). Claustre et al. (1994) suggested than the higher content of Dd per unit of chl $a$ in diatoms confers an adaptive advantage in

allowing a fast acclimation along sharp gradients of light. Resuspension of benthic diatoms could also be tracked from a $12 \mathrm{~h}$ periodicity in $\mathrm{Dd} / \mathrm{chl} a$ at a coastal station in the English Channel (Brunet and Lizon, 2003), and altogether, these in situ data support the 
observation of an increased Dd content in diatoms exposed to fluctuating high light (Lavaud et al., 2002a).

It has been hypothesized that the habitat characteristics account for the observed differences in photoacclimative responses between species, including the long term variations in cellular chla content (Sakshaug et al., 1987), or the potential activity and efficiency of XC (Lavaud et al., 2004; Lavaud et al., 2007; Dimier et al., 2007b, 2009a, b). As an example, strains isolated from estuaries show a higher (2.5 to 5 times) and faster $\mathrm{qE}$ than strains isolated from the open ocean or from coastal ecosystems (Lavaud et $a l ., 2007)$. The difference in photoprotection ability between open ocean and coastal Thalassiosira species may also be due to an adaptation to low or high iron concentrations, respectively (Strzepek and Harrison, 2004).

Few papers have investigated the XC in microalgae other than diatoms (e.g., CasperLindley and Bjorkman, 1998; Moisan et al., 1998; Evens et al., 2001; Harris et al., 2005), limiting the value of comparative ecological and/or evolutionary interpretations within phytoplankton. Some recent studies have focused on picoplanktonic species such as cyanobacteria (Cadoret et al., 2004; Bailey et al., 2005; Wilson et al., 2006) or picoeukaryotes (Dimier et al., 2007a, 2009a, b). Despite the caution needed when generalizing results from single strains, there seems to be an effect of small size on the reactivity of the XC when compared to larger cells (Dimier et al., 2009a). On the other hand, picoeukaryotes are also able to adopt an alternative photoprotective strategy, by rapidly modifying their chl $a$ content ( less than one hour, Brunet et al., 2006, 2007).

The "light history" of the cell, which is the sum of past light variations experienced by the cell, is a key factor to consider when interpreting the dynamics of photoresponses (e.g. Moisan et al., 1998; Anning et al., 2000; Lavaud et al., 2002a). Although this aspect is very difficult, if not impossible, to assess for natural populations, evidences from cultures point to a major role of past light experience on the mode and the kinetics of light-induced reactions. As an example, previous acclimation to high or medium irradiance strongly influences the short-term photoprotective response to a further increase in irradiance, when compared to cells acclimated to lower light (Casper-Lindley and Bjorkman, 1998; Moisan et al., 1998; Dimier et al., 2007b). 
In general, the physiological condition of algal cells has a strong influence on the functioning of the XC. Several authors have observed an increase in the XCP content with no parallel change in light conditions in stressed phytoplankton (e.g. Latasa and Berdalet, 1994; Brunet et al., 1996; Staehr et al., 2002). An increase of Dt has also been observed in diatoms exposed to toxic polyunsaturated aldehydes (Casotti et al., 2005), while inhibition of Dt epoxidation has been caused by Cd (Bertrand et al., 2001). These responses might be interpreted as related to the potential antioxidant role of Dt, as it has been hypothesized for zeaxanthin in higher plants (Strzalka et al., 2003).

\subsubsection{The xanthophyll cycle and UV radiation}

Depletion of the stratospheric ozone layer has resulted in increased UV-B radiation (280-320 nm) which can penetrate down to 30 meters in ocean waters (1\% irradiance depth for $305 \mathrm{~nm}$, Tedetti and Sempéré, 2006) and can potentially damage aquatic organisms, notably phytoplankton (e.g. Vincent and Roy, 1993). Two of the major targets of UV damage in phytoplankton are the photosystem (PS) II reaction centre complex and the carbon-fixing enzyme Rubisco (cf. review by Vincent and Neale, 2000). This damage to both the light and dark reactions of photosynthesis will reduce photochemical use of light energy and thus increase excess light energy, favoring the formation of dangerous reactive oxygen species (ROS) within the cell. Thus mechanisms that can protect against excess light energy, such as the xanthophyll cycle, should be solicited. Indeed, a number of studies from recent years have shown a stimulation of the xanthophyll cycle when algae were exposed to enhanced UV-B under field or light-simulated environment (including realistic levels of photosynthetically active radiation, PAR, and UV-A: 320$400 \mathrm{~nm}$ ). These studies covered a range of algal groups, including diatoms (Goss et al., 1999; Zudaire and Roy, 2001), dinoflagellates (with clear intra-specific, strain-related differences: Laurion and Roy, 2009), haptophytes (Döhler and Haas, 1995; Buma et al., 2000), eustigmatophytes (Sobrino et al., 2005), natural phytoplankton (Döhler and Hagmeier, 1997), and green macroalgae (Choo et al., 2005). In most of these cases, an increase of the de-epoxidized pigment (diatoxanthin or zeaxanthin) was observed, while the epoxidized parent (diadinoxanthin or violaxanthin) decreased, and this correlated with 
a decrease in photochemical efficiency $(\mathrm{Fv} / \mathrm{Fm})$ and an increase in non-photochemical quenching (NPQ) (cf. Goss et al., 1999). In one study, both diadinoxanthin and diatoxanthin increased, which may be attributed to the longer duration of the experiment (4 days, Buma et al., 2000). Sobrino et al. (2005) determined the biological weighting function (BWF, or action spectrum) for xanthophyll de-epoxidation induced by UV radiation (in the presence of realistic PAR levels), showing that both increased irradiance and inclusion of lower wavelengths in the UV range led to more extensive deepoxidation. The BWF was similar in shape to the BWF for UV inhibition of photosynthesis, but with a 22 -fold lower effectiveness. These results indicate that for the species used by Sobrino et al. (2005), stimulation of the xanthophyll cycle occurred upon UV exposure, but this was not sufficient to fully prevent UV inhibition of photosynthesis. Therefore, although xanthophyll de-epoxidation is affected by UV radiation, its main function is related to protection from excess PAR (Sobrino et al., 2005).

A second group of studies have reported no effect on the concentration of xanthophyll pigments upon exposure to UV radiation, although information on the level of deepoxidation was not always available. These studies included work on diatoms (Buma et al., 1996) including benthic species from oyster ponds (Rech et al., 2005) and the Antarctic Chaetoceros brevis (Van de Poll et al., 2005), green algae (Lütz et al., 1997; Roleda et al., 2009), Antarctic ice phytoplankton (Schofield et al. 1995), a toxic dinoflagellate (Evens et al., 2001) and coastal phytoplankton communities exposed to enhanced UV-B in floating mesocosms (Mohovic et al., 2006; Roy et al., 2006). The lack of response was attributed to factors such as interspecific differences, the production of UV-absorbing mucilage, or greater effects of PAR and UV-A. The physiological condition of the cells influenced this response, with a stimulation of the $\mathrm{XC}$ when condition declined (Mohovic et al., 2006). The detection of UV-B induced effects on photoprotective pigments in other studies was caused by a non realistic spectral balance, according to Van de Poll et al. (2005). This, however, does not apply to all cases (e.g. Sobrino et al., 2005).

A last group of studies have shown that UV can inhibit the xanthophyll cycle, generally causing a decrease in the diatoxanthin concentration. Pfündel et al. (1992) showed that UV-B (280-320 $\mathrm{nm}$ ) could inhibit the enzyme violaxanthin deepoxidase in 
isolated pea chloroplasts, preventing the transformation of antheraxanthin into the deepoxidized zeaxanthin. UV-A and UV-B damage to the xanthophyll cycle was observed in cultures of the haptophytes Pavlova spp. (Döhler and Lohmann, 1995), the chlorophyte Dunaliella tertiolecta (Döhler et al. 1997), and of three marine diatoms (Lohmann et al., 1998), including the Antarctic diatom Chaetoceros brevis (Janknegt et al., 2008). Mewes and Richter (2002) reported a UV-B-dependent decrease in diatoxanthin in cultured diatoms caused by an increase in the epoxidation reaction transforming diatoxanthin into diadinoxanthin. The stimulation of DEP by UV-B may be related to the loss of the $\mathrm{pH}$ gradient across the thylakoid membrane which could reduce the affinity of diatoxanthin to its binding site, making it more accessible to DEP. A UV-B-induced loss of the deepoxidized pigment was also observed in studies by Garde and Cailliau (2000) on the haptophyte E. huxleyi and on green macroalgae (Ulva lactuca) exposed to natural sunlight with selective exclusion of UV radiation using screening foils (Bischof et al., 2002,2003 ). The diminished activity (or reversal) of the xanthophyll cycle has also been attributed to enhanced production of ROS (Lichtenthaler, 1998) which can reduce the relative content of diatoxanthin in cells of the marine, near-bottom diatom Cylindrotheca closterium subjected to enhanced UV-B during simulated emersion (Rijstenbil, 2005). This decrease in diatoxanthin was related to UV-A more than to UV-B, and increased salinity exacerbated this reaction. Bischof et al. (2003) also related the reduction in xanthophyll cycle activity to increased production of ROS. Hence both direct (cellular UV targets) and indirect (ROS-related) UV effects can damage the xanthophyll cycle and reduce the diatoxanthin content.

Apparently contradictory conclusions can thus be reached from these recent studies, with the enzyme-mediated xanthophyll cycle being either a potential UVR target or a mechanism stimulated by it. However, detailed examination of the spectral and irradiance conditions reveals that most of the phytoplankton studies reporting a stimulation of the xanthophyll cycle were done under a spectral balance (PAR:UV-A:UV-B) relatively close to that found in nature, with relatively low UV-B levels, while studies reporting inhibition of the xanthophyll cycle were often done under more damaging spectral conditions, sometimes with low PAR levels, no UV-A, and with total UV-B dose often higher than $10 \mathrm{~kJ} \cdot \mathrm{m}^{-2}$. While these studies are useful to unravel the mechanisms of UV 
damage to the xanthophyll cycle, they are less useful to predict effects under natural environmental conditions. Interestingly, there are a few cases where UV-B damage to the xanthophyll cycle has been observed under ecologically-relevant conditions (natural sunlight and high PAR irradiances). These include studies on partly or fully sessile organisms such as benthic diatoms (Rijstenbil, 2005) and macroalgae (e.g. Bischof et al., 2002). Epilithon and other sessile organisms may be more sensitive to UV radiation than free-floating phytoplankton perhaps because they are unable to physically avoid UV stress (Bothwell et al., 1994; Vinebrooke and Leavitt, 1999). Increased oxidative damage could also affect the response of the xanthophyll cycle to UV stress (Bischof et al., 2002; Rijstenbil, 2005). Conceivably, organisms where antioxidant levels are low and oxidative stress is high could show UV damage to the xanthophyll cycle (see Fig. 3). Acclimation may also explain some of the variability in responses of the xanthophyll cycle to UV exposure, with different photoprotection mechanisms alternating through time (Zudaire and Roy, 2001). Lastly, the range of responses to environmental UV radiation is quite large in phytoplankton (Neale et al., 1998), accounting for the variability in size, physiological condition and prior light history. One example of this is the different UV responses observed before, during, and after a bloom of diatoms inside a mesocosm, where the amount of diatoxanthin retained after $24 \mathrm{~h}$ of surface exposure was related to the fraction of inactive PSII reaction centres and was influenced by nitrate limitation (Bouchard et al., 2008). Hence there is not a unique response of the xanthophyll cycle to UV radiation and understanding the overall stress condition of the cells would help elucidate these responses.

\subsubsection{The $\mathrm{XC}$ and the dynamics of water masses}

Several studies have investigated marine ecosystems at different time scales with the aim of characterizing the algal responses to the surrounding light environment through the analysis of the XCPs (e.g. Brunet et al., 1993; Moline, 1998; Brunet et al., 2003; Fujiki et al., 2003; Muller and Wasmund, 2003 for coastal sites, Claustre et al., 1994; Brunet et al., 2003 for frontal systems, Bidigare et al., 1987; Olaizola et al., 1992; Kashino et al., 2002; Brunet et al., 2006, 2007 for offshore areas). 
In situ studies have used different indicators of the photoprotective state of the cells: $(\mathrm{Dd}+\mathrm{Dt}) / \mathrm{chl} a, \mathrm{Dd} / \mathrm{chl} a, \mathrm{Dt} / \mathrm{chl} a$ or also $\mathrm{Dt} /(\mathrm{Dt}+\mathrm{Dd})$. For any of these, when $\mathrm{Dd}$ is included in the numerator, it implies a long-term process (Bidigare et al., 1987), because Dd reacts at much longer time scales than Dt (Lavaud et al., 2002a; Dimier et al., 2007b). Instead, Dt is formed at very short time scales, and it represents a clear indicator of fast activation of photoprotection. The DES (de-epoxidation state) index (Dt/(Dt+Dd) ratio) is often more useful than the ratio Dt/chl $a$ to infer the photoprotective state of a natural phytoplankton community, since the normalization by chla may introduce a bias due to the natural variability of chla related to the physiological state and the light history of cells. In addition, dividing by chl $a$ may be misleading if chla includes algal biomass with no XC (e.g., cyanobacteria) or with the other XC (Vx-cycle in chlorophytes).

Time is a key factor affecting algal physiology. On a yearly scale, photoprotection in terms of any of the above mentioned indices appears to be directly correlated with the daylength and the seasonal increase in total irradiance (Brunet et al., 1993; Moline, 1998; Fujiki et al., 2003). On a diel scale, Dt/chl $a$ and Dt/(Dd+Dt) increase during the daytime and peak around noon (Brunet et al., 1993), while (Dd+Dt)/chla peaks later, due to the longer reactivity time scales of Dd (Moline, 1998). A highly significant relationship with irradiance is generally obtained, with sinusoidal variations of Dt/chla in the upper layer (Brunet et al., 2008).

Phytoplankton is continuously subject to variations in environmental parameters caused by passive displacement due to water mass dynamics, mixing or sinking (Lewis et al., 1984a), or to active displacement due to cell migration. Within a certain time range, mixing triggers short-term photoacclimative responses (MacIntyre et al., 2000), which can be traced and used to monitor physical processes such as upwelling, downwelling, or water mass properties such as transparency.

In the case of rapid mixing, the cells may experience light variations faster than their ability to photoacclimate, while in the case of slow mixing, cells may have the time to acclimate to the average light level (Fig. 4). Indeed, the acclimation rates depend on which parameter is considered, since some responses may require seconds or minutes to be activated (e.g. chl $a$ fluorescence or the XC), while others (e.g., chla content, absorption capacity, photosynthetic parameters) require much longer times (MacIntyre et 
al., 2000; Brunet et al., 2003). The vertical distribution of fast-reacting photodependent parameters (e.g. XC or fluorescence) generally presents a decrease from the very surface to the bottom of the upper mixed layer, as expected from their role in high irradiance protection (Welschmeyer and Hoepffner, 1986; Olaizola et al., 1992; Claustre et al., 1994; Moline, 1998; Brunet et al., 2003, 2006, 2007). However, at times, in actively mixed water columns, homogeneous profiles of XCP have been observed, due to mixing velocities higher than photoacclimation reaction times (Brunet et al., 1993).

Other examples of relationships between physical forcing and algal response come from the use of XCP (e.g. Claustre et al., 1994; Brunet et al., 2003), cell autofluorescence measured by flow cytometry (Dusenberry, 2000) or variable fluorescence (Oliver et al., 2003). Many of these authors have used the kinetics of phytoplankton photoresponses to estimate mixing velocities. As an example, Claustre et al. (1994), Brunet et al. (2003, 2008) estimated, in two different areas of the Mediterranean Sea, vertical mixing velocities between $510^{-4}$ and $710^{-4} \mathrm{~m} \cdot \mathrm{sec}^{-1}$, which are realistic values for the areas investigated (see also Falkowki, 1983; Dusenberry, 2000). Thompson et al. (2007) found significant differences in vertical mixing velocities $\left(510^{-3}\right.$ vs. $\left.810^{-3} \mathrm{~m} \cdot \mathrm{sec}^{-1}\right)$ using XCP distribution between two strongly dynamics eddies in the South-eastern Indian ocean.

The value of these investigations lies in that mixing rates are very difficult parameters to measure directly. From their results on XCP dynamics, Brunet et al. (2003; 2008) compared the percentage variations of different photodependent parameters at the surface or the bottom of the mixed layer and were able to establish a decreasing hierarchy in velocity of photodependent indicators. From the inferred kinetic coefficients, a threshold value of $4 \% \mathrm{~h}^{-1}$ was estimated as the value below which photoacclimation reactions were not significant with respect to the physical dynamics. From this, the vertical eddy diffusivity at the time of sampling could be estimated to be $1.7510^{-2} \mathrm{~m}^{2} \mathrm{sec}^{-1}$ (Brunet $e$ t al., 2003), calculated according to Lewis et al. (1984b) and Cullen and Lewis (1988). This example shows how the analysis of the vertical profiles of photo-dependent parameters may provide valuable insights into the effects of hydrodynamism on algal physiology.

In order to use pigments to infer physical properties and dynamics of water masses, knowledge of the kinetics of changes in photo-physiological parameters is needed. These 
can be retrieved from laboratory (e.g., Falkowski, 1983) or in situ-simulated experiments using natural phytoplankton communities incubated under natural light (deck incubations), subjected to shifts in light intensities. The latter may provide useful terms of comparison to interpret in situ observations, but the appropriate sampling pace must be chosen to obtain statistically sound data (Claustre et al., 1994; Brunet et al., 2003). During the incubations, the photoacclimative dynamics is generally described by a firstorder kinetic equation, from which the kinetic coefficient $\mathrm{K}$ is retrieved (Falkowski, 1983; Claustre et al., 1994). Alternatively, the use of a logistic model allows the consideration of hysteresis, i.e. the influence of the light experienced by the cell before the sampling (light history) which may have a crucial role in the cell response, modulating its kinetics according to the sign of the light change (Cullen and Lewis, 1988). This model has been successfully applied by Cullen and Lewis (1988) and Dusenberry (2000) but remains to be tested on XCP dynamics.

In general, caution must be adopted when using photoprotective pigments as markers of phytoplankton dynamics in the water column. First, the approach presented is only valid for algae using Dt and Dd in the xanthophyll cycle and not for those using violaxanthin and zeaxanthin. This is because zeaxanthin is also part of the constitutive antenna system of prokaryotic algae. Second, it is recommended to use Dt - not Dd - as a tracer of short-term photoacclimation, while the ratio Dd/chla is a good alternative when long-term photoacclimation processes are considered, due to the different kinetics of transformation inside the $\mathrm{XC}$. Indeed, it is recommended to use $\mathrm{Dt} /(\mathrm{Dd}+\mathrm{Dt})$ as an indicator of the de-epoxidation state (DES), excluding any normalization by chla.

\section{$\underline{\text { References }}$}

Anning, T., MacIntyre, H.L., Pratt, S.M., Sammes P.J., Gibb, S., Geider, R.J. (2000). Photoacclimation in the marine diatom Skeletonema costatum. Limnol. Oceanogr., 45, 1807-1817.

Bailey, S., Mann, N.H., Robinson, C., Scanlan, D.J. (2005). The occurrence of rapidly reversible non-photochemical quenching of chlorophyll a fluorescence in cyanobacteria. FEBS Letters, 579: 275-280. 
Beer, A., Gundermann, K., Beckmann, J., Büchel, C. (2006). Subunit composition and pigmentation of fucoxanthin-chlorophyll proteins in diatoms: Evidence for a subunit involved in diadinoxanthin and diatoxanthin binding. Biochemistry 45: 13046-13053.

Berthos, N.R., Gibbs, S.P. (1998). Evidence for a lack of photosystem segregation in Chlamydomonas reinhardtii (Chlorophyceae). J. Phycol. 34: 1009-1016.

Bertrand, M., Schoefs, B., Rohacek, K., Molnar, I. (2001). Cadmium inhibits epoxidation of diatoxanthin to diadinoxanthin in the xanthophyll cycle of the marine diatom Phaeodactylum tricornutum. FEBS Letters, 508: 153-156.

Bidigare, R.R., Smith, R.C., Baker, K.S., Marra, J. (1987). Oceanic primary production estimates from measurements of spectral irradiance and pigment concentrations. Global Biogeochemical cycle, 1: 171-186.

Bischof, K., Kräbs, G., Wiencke, C., Hanelt, D. (2002). Solar ultraviolet radiation affects the activity of ribulose-1,5-biphosphate carboxylase-oxygenase and the composition of photosynthetic and xanthophyll cycle pigments in the intertidal green alga Ulva lactuca L. Planta 215: 502-509.

Bischof, K., Janknegt, P.J., Buma, A.G.J., Rijstenbil, J.W., Peralta, G., Breeman, A.M. (2003). Oxidative stress and enzymatic scavenging of superoxide radicals induced by solar UV-B radiation in Ulva canopies from southern Spain. Sci. Mar. 67: 353359.

Blatt, M. R., Weisenseel, M. H., Haupt, W. (1981). A light-dependent current associated with chloroplast aggregation in the alga Vaucheria sessilis. Planta 152: 513-26.

Bothwell, M.L., Sherbot, D.M.J., Pollock, C.M. (1994). Ecosystem response to solar ultraviolet-B radiation: influence of trophic-level interactions. Science 265: $97-$ 100.

Bouchard, J.N., Longhi, M.L., Roy, S., Campbell, D.A., Ferreyra, G. (2008). Interaction of nitrogen status and UVB sensitivity in a temperate phytoplankton assemblage. J. Exp. Mar. Biol. Ecol. 359: 67-76.

Brunet, C., Brylinski, J.M., Lemoine, Y. (1993). In situ variations of the xanthophylls diadinoxanthin and diatoxanthin: photoadaptation and relationships with an 
hydrodynamical system of the Eastern English Channel. Mar. Ecol. Prog. Ser. 102: 69-77.

Brunet, C., Davoult, D., Casotti, R. (1996). Physiological reactions to a change in light regime in cultured Skeletonema costatum (Bacillariophyta): implications to estimation of phytoplankton biomass. Hydrobiologia 333: 87-94.

Brunet, C., Lizon, F. (2003). Tidal and diel periodicities of size fractionated phytoplankton pigment signatures at an offshore station in the South-Eastern English Channel. Estuarine, Coastal and Shelf Sciences 56: 835-845.

Brunet, C., Casotti, R., Vantrepotte, V., Corato, F., Conversano, F. (2006). Picophytoplankton diversity and photophysiology in the Strait of Sicily (Mediterranean Sea) in summer. I. Mesoscale variations. Aquat. Microb. Ecol. 44:127-141.

Brunet, C., Casotti, R., Vantrepotte, V., Conversano, F. (2007). Vertical variability and diel dynamics of picophytoplankton in the Strait of Sicily, Mediterranean Sea, in summer. Mar. Ecol. Prog. Ser. 346: 15-26.

Brunet, C., Casotti, R., Aronne, B., Vantrepotte, V. (2003). Measured photophysiological parameters used as tools to estimate vertical water movements in the coastal Mediterranean. J. Plankton Res. 25: 1413-1425.

Brunet, C., Casotti, R., Vantrepotte, V. (2008). Phytoplankton diel and vertical variability in photobiological responses at a coastal station in the Mediterranean Sea. J. Plankton Res. 30: 645-654.

Büchel, C. (2003). Fucoxanthin-chlorophyll proteins in diatoms: 18 and 19 kDa subunits assemble into different oligomeric states. Biochemistry 42: 13027-13034.

Buma, A.G.J., Zemmelink, H.J., Sjollema, K., Gieskes, W.W.C. (1996). UVB radiation modifies protein and photosynthetic pigment content, volume and ultrastructure of marine diatoms. Mar. Ecol. Prog. Ser. 142: 47-54.

Buma, A.G.J., van Oijen, T., van de Poll, W., Veldhuis, M.J.W., Gieskes, W.W.C. (2000). The sensitivity of Emiliania huxleyi (prymnesiophyceae) to ultraviolet-B radiation. J. Phycol. 36: 296-303. 
Cadoret, J.C., Démoulière, R., Lavaud, J., van Gorkom, H., Houmard, J., Etienne, A.-L. (2004) Dissipation of excess energy triggered by blue light in cyanobacteria with CP43' (isiA). Biochim. Biophys. Acta 1659: 100-104.

Casotti, R., Mazza, S., Brunet, C., Vantrepotte, V., Ianora, A., Miralto A. (2005). Growth inhibition and toxicity of the diatom aldehyde 2-trans-4-trans decadienal on Thalassiosira weissflogii (Bacillariophyceae). J. Phycol. 41: 7-20.

Casper-Lindley, C., Bjorkman, O. (1998). Fluorescence quenching in 4 unicellular alage with different light-harvesting and xanthophyll-cycle pigments. Photosynthesis res. 56: 277-289.

Choo, K.S., Nilsson, J., Pedersén, M., Snoeijs, P. (2005). Photosynthesis, carbon uptake and antioxidant defence in two coexisting filamentous green algae under different stress conditions. Mar. Ecol. Prog. Ser. 292: 127-138.

Claustre, H., Kerhervé, P., Marty, J.C., Prieur L. (1994). Phytoplankton photoadaptation related to some frontal physical processes. J. Mar. Systems 5: 251-265.

Cogdell, R. J. (2006) The structural basis of non-photochemical quenching revealed ? Trends in plant science 11: 59-60.

Cullen, J.J., Lewis, M.R. (1988). The kinetics of algal photoadaptation in the content of vertical mixing. J. Plankton Res. 10: 1039-1063.

Demers, S., Roy, S., Gagnon, R., Vignault, C. (1991). Rapid light-induced changes in cell fluorescence and in xantophyll-cycle pigments of Alexandrium excavatum (Dinophyceae) and Thalassiosira pseudonana (Bacillariophyceae) a photoprotection mechanism. Mar. Ecol. Prog. Ser. 76: 185-193.

Demmig-Adams, B. (1990). Carotenoids and photoprotection in plants: a role for the xanthophyll zeaxanthin. Biochim. Biophys. Acta 1020: 1-24.

Demmig-Adams, B., Adams, III W.W. (1996). The role of xanthophyll cycle carotenoids in the protection of photosynthesis. Trends in plant science 1: 21-26.

Demmig-Adams, B., Adams, III W.W. (2000). Harvesting sunlight safely. Nature 403: 371-374.

Dimier, C., Saviello, G., Tramontano, F., Brunet, C. (2009a). Comparative ecophysiology of the xanthophyll cycle in six marine phytoplanktonic species. Protist 160: 397411. 
Dimier, C., Brunet, C., Geider, R., Raven, J. (2009b). Growth and photoregulation dynamics of the picoeukaryote Pelagomonas calceolata in fluctuating light. Limnol. Oceanogr., 54: 823-836.

Dimier, C., Corato, F., Saviello, G., Brunet, C. (2007a). Photophysiological properties of the marine picoeukaryote Picochlorum RCC237 (Trebouxiophyceae, Chlorophyta). J. Phycol. 45: 275-283.

Dimier, C., Corato, F., Tramontano, F., Brunet, C. (2007b). Photoprotection and xanthophyll cycle activity in three diatoms. J. Phycol. 43,: 937-947.

Döhler, G., Haas, F.T. (1995). UV effects on chlorophylls and carotenoids of the haptophycean alga Pavlova. Photosynthetica 31: 157-160.

Döhler, G., Lohmann, M. (1995). Impact of UV radiation of different wavebands on the pigmentation of the haptophycean Pavlova. J. Photochem. Photobiol. B: Biology 27: 265-270.

Döhler, G., Hagmeier, E. (1997). UV effects on pigments and assimilation of ${ }^{15} \mathrm{~N}$ ammonium and ${ }^{15} \mathrm{~N}$-nitrate by natural marine phytoplankton of the North Sea. Bot. Acta 110: 481-488.

Döhler, G., Drebes, G., Lohmann, M. (1997). Effects of UV-A and UV-B radiation on pigments, free amino acids and adenylate content of Dunaliella tertiolecta Butcher (Chlorophyta). J. Photochem. Photobiol. B: Biology 40: 126-131.

Dusenberry, J.A. (2000). Steady-state single cell model simulations of photoacclimation in a vertically mixed layer: implications for biological tracer studies and primary productivity. J. Mar. Systems 24: 201-220.

Egeland, E.S., Eikrem, W., Throndsen, J., Wilhelm, C., Zapata, M., Liaaen-Jensen, S. (1995). Carotenoids from further prasinophytes. Biochem. Syst. Ecol. 23:747-55.

Evens, T.J., Kirkpatrick, G.J., Millie, D.F., Chapman, D.J., Schofield, O.M.E. (2001). Photophysiological responses of the toxic red-tide dinoflagellate Gymnodinium breve (Dinophyceae) under natural sunlight. J. Plankton Res. 23: 1177-1193.

Falkowski, P.G. (1983). Light-shade adaptation and vertical mixing of marine phytoplankton: a comparative field study. J. Mar. Res. 41: 215-237.

Falkowski, P.G., Laroche, J. (1991). Acclimation to spectral irradiance in algae. J. Phycol. 27: 8-14. 
Falkowski, P.G., Chen, Y-B. (2003). Photoacclimation of light harvesting systems in eukaryotic algae. In "Light harvesting antennas in photosynthesis" (Beverley R. and Parson W.W., Eds.), 423-447.

Fujiki, T., Toda, T., Kikuchi, T., Taguchi, S. (2003). Photoprotective response of xanthophyll pigments during phytoplankton blooms in Sagami Bay, Japan. $J$. Plankton Res. 25: 317-322.

Garde, K., Cailliau, C. (2000). The impact of UV-B radiation and different PAR intensities on growth, uptake of ${ }^{14} \mathrm{C}$, excretion of $\mathrm{DOC}$, cell volume, and pigmentation in the marine prymnesiophyte, Emiliania huxleyi. J. Exp. Mar. Biol. Ecol. 247: 99-112.

Gilmore, A.M., Yamamoto, H.Y. (1991). Zeaxanthin formation and energy-dependent fluorescence quenching in pea chloroplasts under artificially mediated linear and cyclic electron transport. Plant Physiol. 96: 635-643.

Goss, R., Ann Pinto, E., Wilhelm, C., Richter, M. (2006). The importance of a highly active and delta-pH-regulated diatoxanthin epoxidase for the regulation of the PS II antenna function in diadinoxanthin cycle containing algae. J. Plant Physiol. 163: 1008-1021.

Goss, R., Bohme, K., Wilhelm, C. (1998). The xanthophyll cycle of Mantoniella squamata converts violaxanthin into antheraxanthin but not to zeaxanthinconsequences for the mechanism of enhanced non-photochemical energy dissipation. Planta 205: 613-621.

Goss, R., Lohr, M., Latowski, D., Grzyb, J., Vieler, A., Wilhelm, C., Strzalka, K. (2005). Role of hexagonal structure-forming lipids in diadinoxanthin and violaxanthin solubilization and de-epoxidation. Biochemistry 44: 4028-4036.

Goss, R., Mewes, H., Wilhelm, C. (1999). Stimulation of the diadinoxanthin cycle by UV-B radiation in the diatom Phaeodactylum tricornutum. Photos. Res. 59: 7380.

Green, B.R., Anderson, J.M., Parson, W.W. (2003). Photosynthetic membranes and their light-harvesting antennas. In: Green, B.R. and Parson, W.W. (eds.), Lightharvesting antennas in photosynthesis, Kluwer Academic Publishers, Dordrecht, the Netherlands, 1-28. 
Grouneva, I, Jakob, T, Wilhelm, C, Goss, R (2006). Influence of ascorbate and pH on the activity of the xanthophyll cycle-enzyme diadinoxanthin de-epoxidase. Physiol. Plant. 126: 205-211.

Guglielmi, G., Lavaud, J., Rousseau, B., Etienne, A.-L., Houmard, J., Ruban, A.V. (2005). The light-harvesting antenna of the diatom Phaeodactylum tricornutum Evidence for a diadinoxanthin-binding subcomplex. FEBS Letters 272: 43394348.

Harris, G.N., Scanlan, D.J., Geider, R.J. (2005). Acclimation of Emiliania huxleyi (Prymnesiophyceae) to photon flux density. J. Phycol. 41: 851-862.

Herzig, R., Dubinsky, Z. (1993). Effect of Photoacclimation on the Energy Partitioning between Cyclic and Non-Cyclic Photophosphorylation. New Phytol. 123: 665672.

Hooks, C.E., Bidigare, R. R., Keller, M. D., Guillard, R. R. L. (1988). Coccoid eukariotic marine ultraplankters with four different HPLC pigment signatures. J. Phycol. 24:571-80.

Holt, N. E., Fleming, G. R., Niyogi, K. K. (2004). Toward an understanding of the mechanism of the nonphotochemical quenching in green plants. Biochemistry 43: 8281-8289.

Horton, P., Wentworth, M., Ruban, A. (2005). Control of the light-harvesting function of chloroplast membranes: The LHCII-aggregation model for non-photochemical quenching. FEBS Letters 579: 4201-4206.

Jakob, T., Goss, R., Wilhelm, C. (1999). Activation of diadinoxanthin de-epoxidase due to a chlororespiratory proton gradient in the dark in the diatom Phaeodactylum tricornutum. Plant Biol. 1: 76-82.

Jakob, T., Goss, R., Wilhelm, C. (2001). Unusual pH-dependence of diadinoxanthin deepoxidase activation causes chlororespiratory induced accumulation of diatoxanthin in the diatom Phaeodactylum tricornutum. J. Plant Physiol. 158: 383-390.

Janknegt, van de Poll, W.H., Visser, R.J.W., Rijstenbil, J.W., Buma, A.G.J. (2008). Oxidative stress responses in the marine antarctic diatom Chaetoceros brevis (Bacillariophyceae) during photoacclimation. J. Phycol. 44: 957-966. 
Johnsen, G., Sakshaug, E. (1993). Bio-optical characteristics and photoadaptive responses in the toxic and bloom-forming dinoflagellates Gyrodinium aureolum, Gymnodinium galatheanum, and two strains of Prorocentrum minimum. J. Phycol. 29: 627-42.

Johnsen, G., Nelson, N.B., Jovine, R.V.M., Prézelin, B.B. (1994). Chromoprotein- and pigment-dependent modeling of spectral light absorption in two dinoflagellates, Prorocentrum minimum and Heterocapsa pygmaea. Mar. Ecol. Prog. Ser. 114: 245-58.

Johnsen, G., Sakshaug, E. (2007). Bio-optical characteristics of PSII and PSI in 33 species (13 pigment-groups) of marine phytoplankton, and the relevance for PAM and FRR fluorometry. J. Phycol. 43: 1236-1251.

Johnsen, G., Prézelin, B.B., Jovine, R.V.M. (1997). Fluorescence excitation spectra and light utilization in two red tide dinoflagellates. Limnol. Oceanogr. 42: 1166-77.

Jung, H.S., Niyogi, K.K. (2006). Molecular analysis of photoprotection of photosynthesis. In: Demmig-Adams, B., Adams, W. W. I., Mattoo, A. K., (ed.), Photoprotection, Photoinhibition, Gene Regulation And Environment. Kluwer Academic Publishers, Dordrecht, 127-143.

Kashino, Y., Kudoh, S., Hayashi, Y., Suzuki, Y., Odate, T., Hirawake, T., Satoh, K. Fukuchi, M. (2002). Strategies of phytoplankton to perform effective photosynthesis in the North water. Deep-Sea Res.II 49: 5049-5061.

Kashino, Y., Kudoh S. (2003). Concerted response of xanthophyll-cycle pigments in a marine diatom, Chaeotoceros gracilis, to shifts in light condition. Phycological Res. 51: 168-172.

Kirk, J. T. O., Tilney-Bassett, R. A. E. (1978). The Plastids. Their chemistry, structure, growth and inheritance. Elsevier/North-Holland Biomedical Press, Amsterdam. $2^{\text {nd }}$ edition. $960 \mathrm{pp}$.

Kramer, D.M, Sacksteder, C.A, Cruz, J.A. (1999). How acidic is the lumen? Photosynth. Res. 60: 151-163.

Larkum, A.W. (2003). Light-harvesting systems in algae. In: Larkum, A. W., Douglas, S. E., Raven, J. A. (eds), Photosynthesis in algae, Kluwer Academic Publ, Dordrecht, The Netherlands, pp. 277-304. 
Larkum, A.W., Vesk, M. (2003). Algal plastids: Their fine structure and properties. In Larkum, A.W., Douglas, S.E. Raven, J.A. (eds), Photosynthesis in algae, Kluwer Academic Publ, Dordrecht, The Netherlands, pp. 11-28.

Latasa, M., Berdalet, E. (1994). Effect of nitrogen or phosphorus starvation on pigment composition of cultured Heterocapsa sp. J. Plankton Res. 16: 83-94.

Latowski, D., Grzyb, J., Strzalka, K. (2004). The xanthophyll cycle - molecular mechansim and physiological significance. Acta Physiol. Plant. 26: 197-212.

Laurion, I., Roy, S. (2009). Growth and photoprotection in three dinoflagellates (including two strains of Alexandrium tamarense) and one diatom exposed to four weeks of natural and enhanced ultraviolet-b radiation. J. Phycol. 45: 16-33.

Lavaud, J., Kroth, P. (2006) In diatoms, the transthylakoid proton gradient regulates the photoprotective non-photochemical fluorescence quenching beyond its control on the xanthophyll cycle. Plant Cell Physiol. 47: 1010-1016.

Lavaud, J., Rousseau, B., Etienne, A.L. (2002b). In diatoms, a transthylakoidal proton gradient alone is not sufficient for non-photochemical fluorescence quenching. FEBS Letters 523: 163-166.

Lavaud, J., Rousseau, B., Etienne, A.L. (2003) Enrichment of the light-harvesting complex in diadinoxanthin and implications for the nonphotochemical quenching fluorescence quenching in diatoms. Biochemistry 42: 5802-5808

Lavaud, J., Rousseau, B., Etienne, A.L. (2004). General features of photoprotection by energy dissipation in planktonic diatoms (Bacillariophyceae). J. Phycol., 40: 130137.

Lavaud, J., Rousseau, B., van Gorkom, H.J., Etienne, A.L. (2002a). Influence of the Diadinoxanthin Pool Size on Photoprotection in the Marine Planktonic Diatom Phaeodactylum tricornutum. Plant Physiol. 129: 1398-1406.

Lavaud, J., Strzepek, R.F., Kroth, P.G. (2007). Photoprotection capacity differs among diatoms: Possible consequences on the spatial distribution of diatoms related to fluctuations in the underwater light climate. Limnol. Oceanogr. 52: 1188-1194.

Lewis, M.R., Cullen, J.J., Platt, T. (1984a). Relationships between vertical mixing and photoadaptation of phytoplankton: similarity criteria. Mar. Ecol. Prog. Ser. 15: 141-149. 
Lewis, M.R., Horne, E.P.W., Cullen, J.J., Oakey, N.S., Platt, T. (1984b). Turbulent motions may control phytoplankton photosynthesis in the upper ocean. Nature 311: 49-50.

Lichtenthaler, H.K. (1998). The stress concept in plants: an introduction. Ann. N.Y. Acad. Sci. 851: 187-198.

Lichtlé, C., Arsalane, W., Duval, J.C., Passaquet, C. (1995) Characterization of the lightharvesting complex of Gyraudyopsis stellifer (Chrysophyceae) and effect of light stress. J. Phycol. 31: 380-387

Lohmann, M., Döhler, G., Huckenbeck, N., Verdini, S. (1998). Effects of UV radiation of different wavebands on pigmentation, ${ }^{15} \mathrm{~N}$-ammonium uptake, amino acid pools and adenylate contents of marine diatoms. Mar. Biol. 130: 501-507.

Lohr, M., Wilhelm, C. (2001) Xanthophyll synthesis in diatoms: quantification of putative intermediates and comparison of pigment conversion kinetics with rate constants derived from a model. Planta 212: 382-391.

Lütz, C., Seidlitz, H.K., Meindl, U. (1997). Physiological and structural changes in the chloroplast of the green alga Micrasterias denticulata induced by UV-B stimulation. Plant Ecol. 128: 55-64.

MacIntyre, H.L., Kana, T.M., Geider, R.J. 2000. The effect of water motion on shortterm rates of photosynthesis by marine phytoplankton. Trends in Plant Science $5: 12-17$.

Masojidek, J., Kopecky, J., Koblizek, M., Torzillo G. (2004). The xanthophyll cycle in green alage (Chlorophyta): Its role in the photosynthetic apparatus. Plant Biology 6: 342-349.

Masojidek, J., Torzillo, G., Kopecky, J., Koblizek, M., Kopecky, J., Bernardini, P., Sacchi, A., Komenda, J. (1999). Photoadaptation of two members of the Chlorophyta (Scenedesmus and Chlorella) in laboratory and outdoor cultures: changes in chlorophyll fluorescence quenching and the xanthophyll cycle. Planta 209: 126-135.

Mewes, H., Richter, M. (2002). Supplementary ultraviolet-B radiation induces a rapid reversal of the diadinoxanthin cycle in the strong-light exposed diatom Phaeodactylum tricornutum. Plant Physiol. 130: 1527-1535. 
Mitrovic, S.M., Howden, C.G., Bowling, L.C., Buckney, R.T. (2003). Unusual allometry between in situ growth of freshwater phytoplankton under static and fluctuating light environments: possible implications for dominance. J. Plankton Res. 25: 517-526.

Moisan, T.A., Olaizola, M., Mitchell, B.G. (1998). Xanthophyll cycling in Phaeocystis antarctica: changes in cellular fluorescence. Mar. Ecol. Prog. Ser. 169: 113-121.

Mohovic, B., Gianesella, S.M.F., Laurion, I., Roy, S. (2006). Ultraviolet-B photoprotection efficiency of mesocosm-enclosed natural phytoplankton communities from different latitudes: Rimouski (Canada) and Ubatuba (Brazil). Photochem. Photobiol. 82: 952-961.

Moline, M.A. (1998). Photoadaptative response during the development of a coastal Antarctic diatom bloom and relationship to water column stability. Limnol. Oceanogr. 43: 146-153.

Muller, A.M., Wasmund, N. (2003). Photophysiology of surface phytoplankton communities in a transect from the mouth of the Peene-strom to the Arkona Sea (Baltic). Internat. Rev. Hydrobiol. 88: 482-497.

Neale, P.J., Cullen, J.J., Davis, R.F. (1998). Inhibition of marine photosynthesis by ultraviolet radiation: variable sensitivity of phytoplankton in the Weddell-Scotia Sea during the austral spring. Limnol. Oceanogr. 43: 433-448.

Nielsen, M., Sakshaug, E. (1993). Adaptation to spectrally different light regimes: Studies of the growth rate and Carbon to Chlorophyll $a$ ratio of the marine diatom Skeletonema costatum. Limnol. Oceanogr. 38: 1576-1581.

Olaizola, M., Bienfang, P.K., Ziemann, D.A. (1992). Pigment analysis of phytoplankton during a subarctic bloom: xanthophyll cycling. J. Exp. Mar. Biol. Ecol. 158 : 5974.

Olaizola, M., La Roche, J., Kolber, Z., Falkowski, P.G. (1994). Non-photochemical quenching and the diadinoxanthin cycle in a marine diatom. Photosynthesis Res. 41: 357-370.

Olaizola, M., Yamamoto, H.Y. (1994). Short term response of the diadinoxanthin cycle and fluorescence yield to high irradiance in Chaetoceros muelleri (Bacillariophyceae). J. Phycol. 30: 606-612. 
Oliver, R.L., Whittington, J., Lorenz, Z., Webster, I.T. (2003). The influence of vertical mixing on the photoinhibition of variable chlorophyll $a$ fluorescence and its inclusion in a model of phytoplankton photosynthesis. J. Plankton Res. 25: 11071129.

Owens, T.G. (1986). Light-harvesting function in the diatom Phaeodactylum tricornutum II. Distribution of excitation energy between the photosystems. Plant Physiol. 80: 739-746.

Pfündel, E.E., Pan, R.S., Dilley, R.A. (1992). Inhibition of violaxanthin de-epoxidation by ultraviolet-B radiation in isolated chloroplasts and intact leaves. Plant Physiol. 98: $1372-1380$.

Raniello, R., Lorenti, M., Brunet, C., Buia, M.C. (2006) Photoacclimation of the invasive alga Caulerpa racemosa var. cylindrica to depth and daylight patterns and a putative role for siphonaxanthin. Mar. Ecol. 27: 20-30.

Rascher, U., Nedbal, L. (2006). Dynamics of photosynthesis in fluctuating light. Curr. Opin. Plant Biol. 9: 671-678.

Raven, J.A., Geider, R.J. (2003). Adaptation, acclimation and regulation in algal photosynthesis. In: Photosynthesis in algae, Larkum, A. W., Douglas, S. E. and Raven, J. A. (Eds), Kluwer acedemic publ, Dordrecht, The Nethertlands, p. 386412.

Rech, M., Mouget, J.L., Morant-Manceau, A., Rosa, P., Tremblin, G. (2005). Long-term acclimation to UV radiation: effects on growth, photosynthesis and carbonic anhydrase activity in marine diatoms. Bot. Mar. 48: 407-420.

Rijstenbil, J.W. (2005). UV-and salinity-induced oxidative effects in the marine diatom Cylindrotheca closterium during simulated emersion. Mar. Biol. 147: 1063-1073.

Ritz, M., Neverov, K.V., Etienne, A.L. (1999). $\Delta \mathrm{pH}$-dependent fluorescence quenching and its photoprotective role in the unicellular red alga Rhodella violacea. Photosynthetica 37: 267-280.

Rodriguez, F., Chauton, M., Johnsen, G., Andresen, K., Olsen, L.M., Zapata, M. (2006). Photoacclimation in phytoplankton: implications for biomass estimates, pigment functionality and chemotaxonomy. Mar. Biol. 148: 963-971. 
Roleda, M.Y., Campana, G.L., Wiencke, W., Hanelt, D., Quartino, M.L., Wulff, A. (2009). Sensitivity of Antarctic Urospora penicilliformis (Ulotrichales, Chlorophyta) to ultraviolet radiaton is life-stage dependent. J. Phycol. 45: 600609.

Roy, S., Mohovic, B., Gianesella, S.M.F., Schloss, I., Ferrario, M., Demers, S. (2006). Effects of enhanced UV-B on pigment-based phytoplankton biomass and composition of mesocosm-enclosed natural marine communities from three latitudes. Photochem. Photobiol. 82: 909-922.

Ruban, A.V., Lavaud, J., Rousseau, B., Guglielmi, G., Horton, P., Etienne A.L. (2004). The super-excess energy dissipation in diatom algae: comparative analysis with higher plants. Photosynthesis Res. 82: 165-175.

Sakshaug, E., Demers, S., Yentsch , C.M. (1987). Thalassiosira oceanica and T. pseudonana: Two different photoadaptational responses. Mar. Ecol. Prog. Ser. 41: $275-82$.

Sakshaug, E., Johnsen, G. (2005). Absorption, fluorescence excitation and photoacclimation in phytoplankton. In Rao, S. (ed.). Algal cultures, Analogues of Blooms and Applications. Science Press Publ. Chapter 19: pp. 687-714.

Sakshaug, E., Bricaud, A., Dandonneau, Y., Falkowski, P.G., Kiefer, D.A., Legendre, L., Morel, A., Parslow, J., Takahashi, M. (1997). Parameters of photosynthesis: definitions, theory and interpretation of results. J. Plankton Res. 19: 1637-1670.

Schofield, O., Kroon, B.M.A., Prézelin, B.B. (1995). Impact of ultraviolet-B radiation on photosystem II activity and its relationship to the inhibition of carbon fixation rates for Antarctic ice algae communities. J. Phycol. 31: 703-715.

Schofield, O., Prézelin, B.B., Johnsen, G. (1996). Wavelength-dependency of maximum quantum yield of carbon fixation for two red tide dinoflagellates, Heterocapsa pygmaea and Prorocentrum minimum. J. Phycol. 32: 574-83.

Serodio, J., Cruz, S., Vieira, S., Brotas, V. (2005). Non-photochemical quenching of chlorophyll fluorescence and operation of the xanthophyll cycle in estuarine microphytobenthos. J. Exp. Mar. Biol. Ecol. 326: 157-169. 
Sobrino, C., Neale, P.J., Montero, O., Lubián, L.M. (2005). Biological weighting function for xanthophyll de-epoxidation induced by ultraviolet radiation. Physiol. Plant. 125: 41-51.

Staehr, P.A., Henriksen, P., Markager, S. (2002). Photoacclimation of four marine phytoplankton species to irradiance and nutrient availability. Mar. Ecol. Prog. Ser. 238: 47-59.

Stolte, W., Kraay, G.W., Noordeloos, A.A.M., Riegman, R. (2000). Genetic and physiological variation in pigment composition of Emiliania huxleyi (prymnesiophyceae) and the potential use of its pigment rations as a quantitative physiological marker. J. Phycol. 36: 529-539.

Strzalka, K., Kostecka-Gugala, A., Latowski, D. (2003). Carotenoids and environmental stress in plants: significance of carotenoid-mediated modulation of membrane physical properties. Russian Journal of Plant Physiology, 50: 168-172.

Strzepek, R.F., Harrison, P.J. (2004). Photosynthetic architecture differs in costal and oceanic diatoms. Nature 431: 689-692.

Tedetti, M., Sempéré, R. (2006). Penetration of ultraviolet radiation in the marine environment. A review. Photochem. Photobiol. 82: 389-397.

Thompson, P.A., Pesant, S., Waite, A.M. (2007). Contrasting the vertical differences in the phytoplankton biology of a dipole pair of eddies in the south-eastern Indian Ocean. Deep sea Res. II. 54: 1003-1028.

Ursi, S., Pedersén, M., Plastino, E., Snoeijs, P. (2003). Intraspecific variation of photosynthesis, respiration and photoprotective carotenoids in Gracilaria birdae Gracilariales (Rhodphyta). Mar. Biol. 142: 997-1007.

Van de Poll, W.H., van Leeuwe, M.A., Roggeveld, J., Buma, A.G.J. (2005). Nutrient limitation and high irradiance acclimation reduce PAR and UV-induced viability loss in the Antarctic diatom Chaetoceros brevis (Bacillariophyceae). J. Phycol. 41: 840-850.

Vincent, W.F., Roy, S. (1993). Solar UV-B effects on aquatic primary production: damage, repair and recovery. Environmental Reviews 1: 1-12.

Vincent, W.F., Neale, P.J. (2000). Mechanisms of UV damage to aquatic organisms. In: de Mora, S., Demers, S., Vernet, M. (eds), The effects of UV radiation in the 
marine environment, Cambridge environmental chemistry series no. 10, Cambridge Univ. Press, Cambridge, p. 149-176.

Vinebrooke, R.D., Leavitt, P.R. (1999). Differential responses of littoral communities to ultraviolet radiation in an alpine lake. Ecology 80: 223-237.

Welschmeyer, N.A., Hoepffner, N. (1986). Rapid xanthophyll cycling: an in situ tracer for mixing in the upper ocean. EOS (Trans. Am. Geophys. Union), 67: 969.

Wilhelm, C., Büchel, C., Fisahn, J., Goss, R., Jakob, T., LaRoche, J., Lavaud, J., Lohr, M., Riebesell, U., Stehfest, K., Kroth, P. (2006). The regulation of carbon and nutrient assimilation in diatoms is significantly different from green algae. Protist 157: $91-124$.

Wilson, A., Ajlani, G., Verbavatz, J.M., Vass, I., Kerfeld, C.A., Kirilovsky, D. (2006). A soluble carotenoid protein involved in phycobilisome-related energy dissipation in cyanobacteria. Plant Cell 18: 992-1007.

Zapata, M., Jeffrey, S W, Wright, S W, Rodriguez, F, Garrido, J.L, Clementson, L, (2004). Photosynthetic pigments in 37 species (65 strains) of Haptophyta: implications for oceanography and chemotaxonomy. Mar. Ecol. Prog. Ser. 270: 83-102.

Zingone, A., Borra, M., Brunet, C., Forlani, G., Kooistra, WHCF., Procaccini, G. (2002). Phylogenetic position of Crustomastix stigmatica sp. nov. and Dolichomastix tenuilepsis in relation to the mamiellales (Prasinophyceae, Chlorophyta). J. Phycol. 38: 1024-1039.

Zudaire, L., Roy, S. (2001). Photoprotection and long-term acclimation to UV radiation in the marine diatom Thalassiosira weissflogii. J. Photochem. Photobiol. B: Biology 62: 26-34.

\section{Acknowledgements}

C.B. would like to thank the Stazione Zoologica A. Dohrn for having made possible his research and for granting PhD students. Two anonymous referees and Dr. Carole Llewellyn are gratefully acknowledged for their helpful comments on the manuscript. 


\section{Table I : List of abbreviations used in this chapter}

$\begin{array}{lll}\text { PPC } & : & \text { Photoprotective carotenoids } \\ \text { ACP } & : & \text { Chla-chlc-peridinin protein } \\ \text { XCP } & : & \text { Xanthophyll-cycling pigments } \\ \text { XC } & : & \text { Xanthophyll-cycle } \\ \text { DDE } & : & \text { Diadinoxanthin de-epoxidase } \\ \text { ZEP } & : & \text { Zeaxanthin epoxidase } \\ \text { VDE } & : & \text { Violaxanthin de-epoxidase } \\ \text { NPQ } & : & \text { Non-photochemical fluorescence quenching } \\ \text { DEP } & : & \text { Diadinoxanthin epoxidase } \\ \text { DES } & : & \text { De-epoxidation state } \\ \text { RC } & : & \text { Photosynthetic reaction centers } \\ \text { PS } & : & \text { Photosystems }\end{array}$


Table II. Distribution of the major photosynthetic phyla according to the nature of their main xanthophyll cycle (XC). Group 3 shows no XC but accumulation of ZX under an excess of light. $\mathrm{H}$ stands for Heterokontophyta. Some phyla, indicated by $*$, have a secondary XC (see the text). VX, violaxanthin; AX, antheraxanthin; ZX, zeaxanthin; DD, diadinoxanthin, DT, diatoxanthin.

\begin{tabular}{|c|c|c|}
\hline Group 1 & Group 2 & Group 3 \\
\hline VX/AX/ZX & DD/DT & No $\mathrm{XC}$ but $\mathrm{ZX}$ accumulation \\
\hline Embryophyta * & Bacillariophyceae* $(\mathrm{H})$ & Cyanophyta \\
\hline Pteridophyta & Xanthophyceae* (H) & Rhodophyta (most species) \\
\hline Bryophyta & Haptophyta * & Glaucocystophyta \\
\hline Chlorophyta * & Dinophyta* & Cryptophyta \\
\hline Phaeophyceae (H) & Raphidophyta & Chlorophyta (some species) \\
\hline Eustigmatophyceae (H) & Euglenophyta & \\
\hline Chrysophyceae* (H) & & \\
\hline $\begin{array}{l}\text { Rhodophyta } \\
\text { (some species) }\end{array}$ & & \\
\hline
\end{tabular}




\section{$\underline{\text { List of Figures }}$}

Fig. 1: Fractional pigment-specific absorption and the effect of the light harvesting pigments and PPC in (A) high light- and (B) low light-acclimated cells of the dinoflagellate Prorocentrum minimum. 1: total pigments; 2: photosynthetic pigments (total pigments minus diadinoxanthin); 3: $\operatorname{chl} a ; 4: \operatorname{chlc}_{2} ; 5$ : peridinin; 6: diadinoxanthin (from Johnsen et al. 1994).

Fig. 2: The xanthophyll cycles and their characteristics (modified from Wilhelm et al, 2006). Asc, Ascorbate; MGDG, Monogalactosyldiacylglycerol lipids, Vx, Violaxanthin; Zx, Zeaxanthin; Dd, Diadinoxanthin; Dt, Diatoxanthin. Co-factor requirement for the enzymes is shown as well as the $\mathrm{pH}$ optimum. The '+' signs indicate the requirement for optimal de-epoxidase activity. '- $\Delta \mathrm{pH}$ ' means that the Dt epoxidase is inhibited by the high stromal $\mathrm{pH}$ under high light exposure.

Fig. 3: A scheme of possible UV-B effects on the XC.

Fig. 4: Relationship between photoprotective parameter and vertical mixing in the euphotic layer of the water column. (a) Photoprotection rate $\left(\mathrm{K}_{\mathrm{ph}}\right)$ is higher than vertical mixing rate $\left(\mathrm{K}_{\mathrm{m}}\right)$ with $\mathrm{K}_{\mathrm{ph}}>\mathrm{K}_{\mathrm{m}}$ (strait line) and $\mathrm{K}_{\mathrm{ph}}>\mathrm{K}_{\mathrm{m}}$ (dashed line); (b) photoprotection rate $\left(\mathrm{K}_{\mathrm{ph}}\right)$ is lower than the vertical mixing rate $\left(\mathrm{K}_{\mathrm{m}}\right)$; (c) photoprotection rate $\left(\mathrm{K}_{\mathrm{ph}}\right)$ is higher than vertical mixing rate $\left(\mathrm{K}_{\mathrm{m}}\right)$ with an advection of surface phytoplankton to a deeper layer in the euphotic zone. Modified from Claustre et al. (1994). 


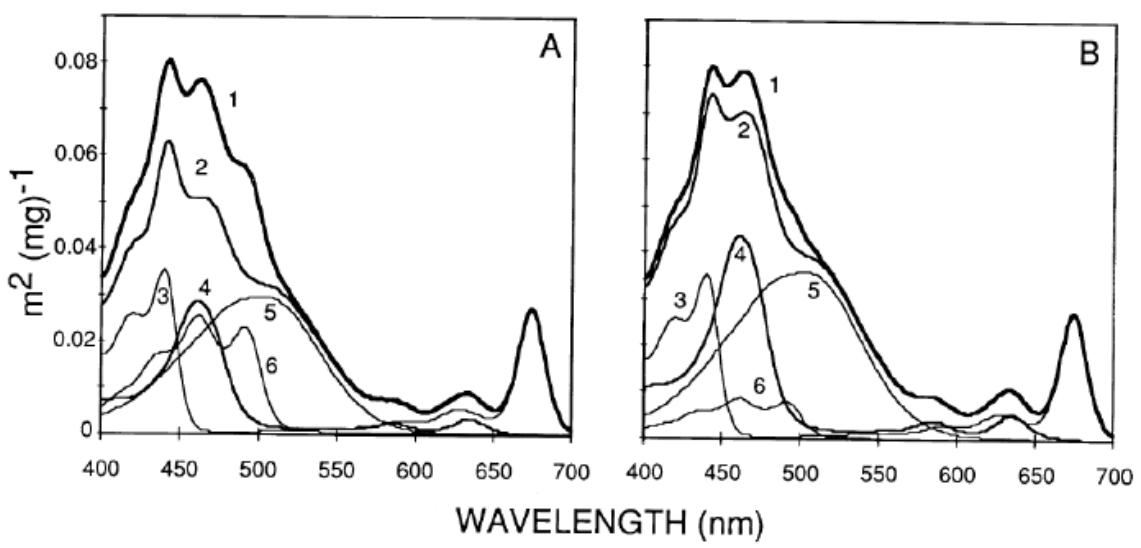

Fig. 1 

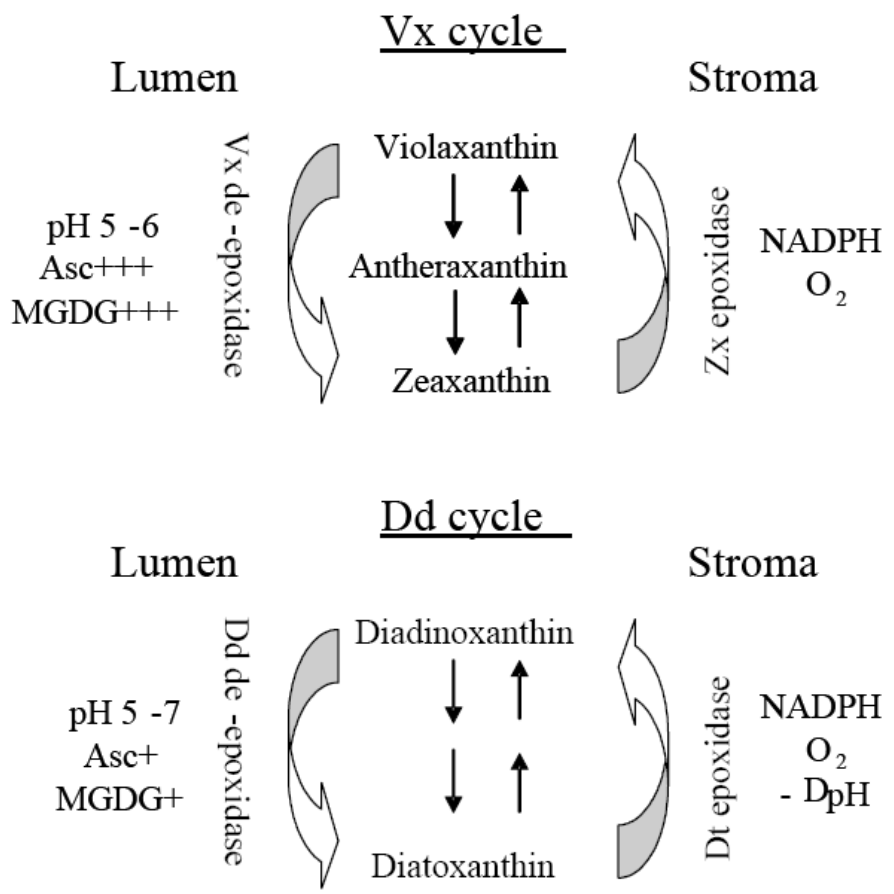

Fig. 2 
$\Uparrow \mathrm{UV} \Rightarrow \Uparrow \mathrm{ROS} \Rightarrow \Uparrow$ Antioxidants

Sufficient level $\Rightarrow$ No damage to XC (介 Dt or Zx)

Insufficient level $\Rightarrow$ Damage to XC $(\Downarrow$ Dt or Zx)

Fig. 3 


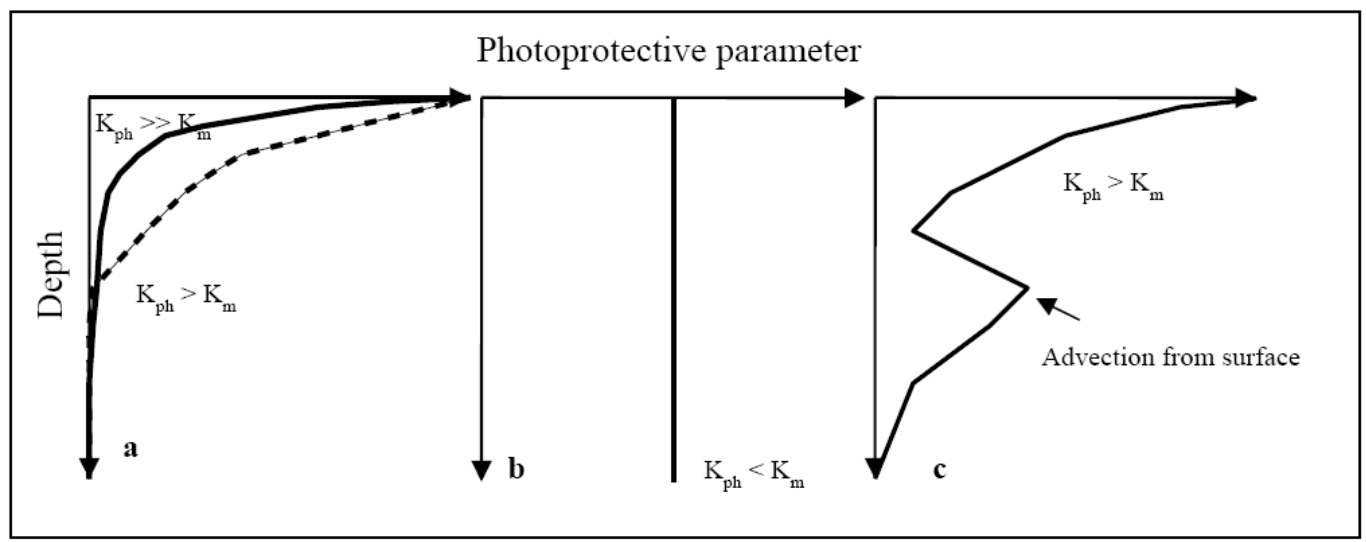

Fig. 4 